\title{
PEMUTIHAN GIGI MENGGUNAKAN BUAH PIR
}

\author{
Ellis Mirawati Hamid, Lucia Yauri
}

\begin{abstract}
ABSTRAK
Masyarakat sering tidak percaya diri ketika tersenyum dan berbicara akibat perubahan warna pada gigi yang mempengaruhi estetika. Gigi yang mengalami perubahan warna dapat memberikan kesan yang kurang indah pada penampilan dan meredam rasa percaya diri saat tersenyum. Faktor ekstrinsik dapat mempengaruhi terjadinya perubahan warna gigi seperti kuning, abu-abu atau coklat kehitaman misalnya konsumsi kopi dan teh juga intrinsik misalnya konsumsi air minum yang mengandung flour melebihi batas normal dalam jangka waktu yang panjang. Salah satu bahan yang sering digunakan oleh praktisi dokter gigi untuk memutihkan gigi adalah Hidrogen peroksida. Pemakaian bahan ini dapat menimbulkan dampak berupa gigi sensitif dan iritasi pada gingiva serta jaringan lunak rongga mulut. Pada penelitian ini menggunakan buah pir sebagai bahan pemutih gigi karena mempunyai efek samping yang minim. Rancangan penelitian ini adalah eksperimental semu dengan menggunakan pre test dan post test with control group design, dengan besar sampel 50 orang dengan menggunakan teknik Simple Random Sampling. Tekhnik analisis data yaitu uji Paired t-test untuk menguji perbedaan $\mathrm{pH}$ sebelum dan setelah pengolesan ekstrak buah pir pada gigi. Berdasarkan uji statistik independent sample t-test dengan nilai $P \quad 0,000(P<0,05)$ menunjukkan terjadi perubahan warna gigi sebelum dan sesudah aplikasi ekstak buah pir.
\end{abstract}

Kata Kunci : buah pir, pemutih gigi, estetika

\section{PENDAHULUAN}

Masyarakat sering tidak percaya diri ketika tersenyum dan berbicara akibat perubahan warna pada gigi yang mempengaruhi estetika. Perubahan warna gigi dapat memberikan kesan kurang indah pada penampilan dan mengurangi rasa percaya diri pada saat tersenyum. Karena senyum yang indah dengan gigi yang bersih dan putih merupakan impian semua orang. Inilah sebab mengapa terjadi peningkatan pelayanan estetik gigi khususnya pemutihan gigi.

Bagian gigi terdiri atas tiga, yaitu mahkota gigi (corona), leher gigi , dan akar gigi (radiks). Gigi bersumber dari dua jaringan embrional, yaitu ektoderm dan mesoderm. Mesoderm, membentuk dentin yang terdapat di dalam email, sementum (lapisan luar akar gigi), dan pulpa (rongga gigi) yang banyak memiliki serabut saraf dan pembuluh darah , sedangkan ektoderm membentuk lapisan luar atau email (Aryulina, 2004).

Ketebalan email, serta ketebalan dan warna dentin yang melapisi di bawahnya, dan warna pulpa menentukan warna pada gigi. Normalnya, warna gigi sulung adalah putih kebiru- biruan sedangkan gigi permanen yaitu kuning keabu-abuan, putih keabu-abuan atau putih kekuning-kuningan. Perubahan ini, dapat bersifat fisiologik dan patologik. Dengan bertambahnya usia, email berubah lebih tipis karena abrasi atau erosi, dan dentin menjadi lebih tebal karena deposisi dentin sekunder yang menghasilkan perubahan warna pada gigi selama hidup seseorang itulah sebabnya gigi orang tua biasanya lebih kuning atau abu-abu kekuningkuningan dibandingkan gigi orang yang lebih muda (Grossman, 1995 ; Adiyanto, 2009).

Menurut Purwanti (2008), perubahan warna gigi (diskolorasi gigi) dapat dipengaruhi oleh berbagai faktor, yaitu faktor dari luar tubuh (ekstrinsik) atau dari dalam tubuh (intrinsik) seperti abu-abu, kuning atau coklat kehitaman (Ciptawening, 2014, Purwanti 2008).

Diskolorasi intrinsik juga dapat diakibatkan kaena masukan flouride kedalam tubuh melebihi nilai batas ambang untuk orang dewasa 8,00-10,00 ppm, dan untuk anak-anak 2,50-3,00 ppm. Berubahnya warna gigi dapat terjadi karena jaringan syaraf gigi rusak, penyakit kelainan darah, benturan kuat pada gigi, pengaruh bahan 
penambalan serta perawatan saluran akar gigi (Ciptawening, 2014 ; Adiyanto, 2009).

Pemutihan gigi sering kali dilakukan masyarakat dengan mengunjungi klinik dokter gigi dengan harapan mereka bisa mendapatkan hasil maksimal seperti yang di inginkan. Pemutihan gigi yang dilakukan di klinik dokter gigi menggunakan bahan kimia yakni hidrogen peroksida.

Hidrogen peroksida adalah salah satu bahan pemutih gigi yang sering ditemukan, bahan ini memiliki fungsi sebagai oksidator kuat yang menghasilkan radikal bebas yang sangat reaktif. Senyawa ini mampu merusak melekul-melekul zat warna sehingga berubah netral dan meyebabkan efek pemutihan. Penggunaan hidrogen peroksida sebaiknya lebih berhati-hati dengan mempertimbangkan efek yang ditimbulkan terutama jika digunakan dalam jangka waktu yang lama, sebab bahan ini adalah senyawa radikal bebas yang sangat berbahaya bagi tubuh. Pemakaian bahan pemutih ini dapat memicu efek samping berupa gigi yang sensitif dan iritasi pada gingiva serta jaringan lunak rongga mulut dan dapat terjadi apabila digunakan secara salah dan tidak semestinya (Tioton.D.A, 1995).

Bahan pemutihan gigi yang menggunakan bahan kimia berupa hidrogen peroksida umumnya hanya dapat bertahan beberapa tahun saja, tergantung bagaimana pasien memiliki motivasi untuk menjaga kebersihan dan kesehatan mulutnya (Riyanti E, 2007).

Berdasarkan dari hasil penelitian, berbagai bahan alami dapat dimanfaatkan sebagai bahan bleaching, antara lain buah strowberi, jeruk, pir dan nanas. Buah pir dapat dimanfaatkan dalam hal pemutihan gigi, karena buah pir mengandung perokside ( $\mathrm{H} 2 \mathrm{O} 2)$. Menurut penelitian yang telah di lakukan oleh Brennan $\mathrm{T}$ dan Intan Oktaviana $\mathrm{A}$, kandungan hidrogen peroksida ( $\mathrm{H} 2 \mathrm{O} 2)$ dalam buah pir dapat dimanfaatkan sebagai bahan pemutih alami yang efektif pada gigi. Hasil dari beberapa penelitian diketahui bahwa yang paling aman sekaligus efektif adalah karbamid peroksida $10 \%$.
Dimana peroksida bertindak sebagai agen oksidator. Karbamid peroksida akan terurai menjadi hydrogen peroksida, dan akan menghasilkan radikal bebas yang akan bereaksi dengan molekul organik dalam email gigi. Karena timbulnya reaksi ini, molekul organik yang berukuran besar dan berpigmentasi tinggi akan menjadi molekul berukuran lebih kecil dan lebih sedikit pigmeen. Molekul kecil ini lebih sedikit merefleksikan cahaya, sehingga hasil akhirnya adalah gigi tampak lebih putih (Pusparatri, 2015).

Banyak keuntungan dari menggunakan buah pir sebagai bahan pemutih gigi alami bila dibandingkan dengan pemutih gigi yang mengandung bahan kimia. Salah satunya ialah buah pir ini selain mudah didapat, harganya masih terjangkau serta mudah dilakukan Oleh karena hal di atas peneliti ingin mencoba memanfaatkan buah pir sebagai bahan alami pemutih gigi dan menguji seberapa efektifitasnya dalam memutihkan gigi.

\section{METODE PENELITIAN}

Jenis penelitian yang digunakan adalah quasi experimental lapangan, yaitu dengan cara sampel dilakukan pemeriksaan sebelum dan sesudah dilakukan treatmant (perlakuan ). Penelitian ini dilakukan di Kompleks Skarda Kelurahan Karungrung Kecamatan Rappocini Makassar Sulawesi Selatan. Teknik pengambilan sampel secara random sampling. Jumlah sampel sebanyak 50 orang penghuni kost di Kompleks Skarda Kelurahan Karungrung Kecamatan Rappocini Makassar Sulawesi Selatan yang memenuhi kriteria peneliti. Metode analisa data dilakukan dengan Analisis uji statistik paired T-tes.

\section{HASIL DAN PEMBAHASAN}

\section{Hasil}

Berikut ini adalah hasil penelitian yang telah dilakukan: 
Tabel 1. Distribusi frekuensi hasil pemeriksaan berdasarkan usia dan jenis kelamin

\begin{tabular}{|c|c|c|c|}
\hline No & Jenis Kelamin & Frekuensi (n) & $\begin{array}{c}\text { Persentase } \\
(\%)\end{array}$ \\
\hline 1 & Laki-laki & 19 & 38.0 \\
\hline 2 & Perempuan & 31 & 62.0 \\
\hline & Total & 50 & 100.0 \\
\hline
\end{tabular}

Tabel 2. Distribusi frekuensi perubahan warna gigi sebelum dan sesudah pengaplikasian ekstrak buah pir

\begin{tabular}{|c|c|c|c|c|}
\hline \multirow[b]{2}{*}{ No } & \multicolumn{2}{|c|}{ Sebelum } & \multicolumn{2}{|c|}{ Sesudah } \\
\hline & $\begin{array}{c}\text { Kode } \\
\text { Warna } \\
\text { Gigi }\end{array}$ & $(\mathrm{N})$ & $\begin{array}{c}\text { Kode } \\
\text { Warna Gigi }\end{array}$ & $(\mathrm{N})$ \\
\hline \multirow{2}{*}{1} & \multirow{2}{*}{ A3 } & \multirow{2}{*}{8} & $\mathrm{~A} 2$ & 7 \\
\hline & & & $\mathrm{A} 1$ & 1 \\
\hline \multirow{2}{*}{2} & \multirow{2}{*}{ B2 } & \multirow{2}{*}{7} & B1 & 6 \\
\hline & & & $\mathrm{A} 1$ & 1 \\
\hline \multirow{2}{*}{3} & \multirow{2}{*}{$A 3,5$} & \multirow{2}{*}{11} & A3 & 10 \\
\hline & & & A3,5 & 1 \\
\hline 4 & $\mathrm{~A} 2$ & 6 & $\mathrm{~A} 1$ & 6 \\
\hline 5 & A1 & 4 & B1 & 4 \\
\hline \multirow{4}{*}{6} & \multirow{4}{*}{ A4 } & \multirow{4}{*}{6} & A3 & 2 \\
\hline & & & A3,5 & 1 \\
\hline & & & A4 & 1 \\
\hline & & & C3 & 2 \\
\hline 7 & B3 & 1 & B1 & 1 \\
\hline 8 & $\mathrm{C} 2$ & 1 & C1 & 1 \\
\hline 9 & C3 & 1 & $\mathrm{C} 2$ & 1 \\
\hline 10 & C4 & 2 & A4 & 2 \\
\hline 11 & C1 & 1 & $\mathrm{~A} 2$ & 1 \\
\hline 12 & D2 & 1 & B2 & 1 \\
\hline 13 & D4 & 1 & $\mathrm{C} 2$ & 1 \\
\hline & mlah & 50 & & 50 \\
\hline
\end{tabular}

Dari tabel 2 didapatkan hasil dari 50 sampel pada penghuni kost kompleks skarda Kelurahan
Karungrung Kecamatan Rappocini Makassar Sulawesi selatan pada tahun 2015 bahwa terdapat 8 orang yang memiliki warna gigi A3 sebelum ditempeli buah pir dan kemudian setelah ditempeli buah pir berubah menjadi A2 sebanyak 7 orang dan $A 1$ sebanyak 1 orang, warna gigi $B 2$ sebanyak 7 orang berubah menjadi B1 sebanyak 1 orang dan A1 sebanyak 1 orang, warna gigi A3,5 sebanyak 11 orang berubah menjadi $A 3$ sebanyak 10 orang dan 1 orang yang tidak mengalami perubahan sama sekali, warna gigi $A 2$ sebanyak 6 orang dan semua mengalami perubahan menjadi $A 1$, warna gigi A1 sebanyak 4 orang dan semua juga mengalami perubahan warna menjadi B1, warna gigi A4 sebanyak 6 orang berubah menjadi $A 3$ dan C3 masing-masing sebanyak 2 orang ,A3,5 sebanyak 1 orang dan 1 orang yang tidak mengalami perubahan sama sekali dan tetap berwarna A4, warna gigi B3 berubah menjadi B1, warna gigi $\mathrm{C} 2$ berubah menjadi $\mathrm{C} 1$, warna gigi $\mathrm{C} 3$ berubah menjadi $\mathrm{C} 2$, warna gigi $\mathrm{C} 1$ berubah menjadi A1, warna gigi D2 berubah menjadi B2, warna gigi D4 berubah menjadi C2 masing-masing sebanyak 1 orang dan terakhir warna gigi C4 sebanyak 2 orang dan semua mengalami perubahan warna menjadi A4.

Table 3. Distribusi frekuensi rata-rata perubahan warna gigi sebelum dan sesudah dilakukan pengaplikasian dengan ekstrak buah pir

\begin{tabular}{|l|c|c|c|c|c|}
\hline & $\begin{array}{c}\text { Rata- } \\
\text { rata }\end{array}$ & $\begin{array}{c}\text { Jumlah } \\
\text { sampel }\end{array}$ & $\begin{array}{c}\text { Std. } \\
\text { Deviation }\end{array}$ & $\begin{array}{c}\text { Std. Error } \\
\text { Mean }\end{array}$ & $p$ \\
\hline Sebelum & 8.70 & 50 & 4.564 & .645 & \\
Sesudah & 5.90 & 50 & 4.455 & .630 & 0,000 \\
\hline
\end{tabular}

Tabel 3. Menunjukkan hasil penelitian efektifitas buah pir terhadap penghuni kost Kompleks Skarda Kelurahan Karungrung Kecamatan Rappocini Makassar Sulawesi Selatan sebanyak 50 sampel rata-rata skor sebelum pengaplikasian dengan buah pir adalah 8.70 dan rata-rata skor setelah pengaplikasian dengan buah pir adalah 5.90, Berdasarkan uji statistik paired t-test 
diperoleh nilai $\mathrm{P}$ 0,000 ( $\mathrm{P}<0,05$ ) artinya terjadi perubahan warna gigi sebelum dan sesudah aplikasi ekstra buah pir.

\section{Pembahasan}

Dari hasil pemeriksaan 50 sampel pada penghuni kost Kompleks Skarda Kelurahan Karungrung Kecamatan Rappocini Makassar Sulawesi Selatan diketahui bahwa terdapat sampel dengan jenis kelamin laki-laki 19 orang (38\%) dan jenis kelamin perempuan sebanyak 31 orang (62\%). Dan hasil pemeriksaan yang dilakukan sebelum perlakuan dengan menggunakan buah pir yang paling banyak didapatkan adalah warna gigi $A 3,5$ sebanyak 11 orang dan berubah warna menjadi A3 sebanyak 10 orang dan ada 1 orang yang tidak mengalami perubahan sama sekali yaitu tetap berwarna A3,5. Banyak hal yang mempengaruhi perubahan warna gigi seperti komsumsi makanan atau minuman yang menyebabkan perubahan warna gigi seperti teh, kopi,soda dan lain sebagainya dan yang paling penting adalah motivasi pasien sendiri untuk menjaga kebersihan gigi dan mulutnya (Riyanti E, 2007).

Pada penelitian ini, pemutihan dilakukan selama 1 minggu dengan cara menempelkan buah pir yang telah dihaluskan pada gigi anterior rahang atas selama 5 menit setiap harinya. Hasilnya, perubahan warna gigi dari A3 yang awalnya sebanyak 8 orang berubah menjadi A2 sebanyak 7 orang dan A1 sebanyak 1 orang, warna gigi B2 sebanyak 7 orang berubah menjadi B1 sebanyak 1 orang dan A1 sebanyak 1 orang, warna gigi $A 3,5$ sebanyak 11 orang berubah menjadi $A 3$ sebanyak 10 orang dan 1 orang yang tidak mengalami perubahan sama sekali, warna gigi A2 sebanyak 6 orang dan semua mengalami perubahan warna menjadi $A 1$, warna gigi $A 1$ sebanyak 4 orang dan semua juga mengalami perubahan warna menjadi B1, warna gigi A4 sebanyak 6 orang berubah menjadi A3 dan C3 masing-masing sebanyak 2 orang ,A3,5 sebanyak 1 orang dan 1 orang yang tidak mengalami perubahan sama sekali dan tetap berwarna A4, warna gigi B3 berubah menjadi B1, warna gigi $\mathrm{C} 2$ berubah menjadi $\mathrm{C} 1$, warna gigi $\mathrm{C} 3$ berubah menjadi C2, warna gigi $\mathrm{C} 1$ berubah menjadi A1, warna gigi D2 berubah menjadi B2, warna gigi D4 berubah menjadi C2 masing-masing sebanyak 1 orang dan terakhir warna gigi C4 sebanyak 2 orang dan semua mengalami perubahan warna menjadi A4.

Penelitian ini, terdapat kesamaan dengan penelitian sebelumnya yang dilakukan oleh Adiyanto Intan Oktaviana pada tahun 2009 dengan perendaman gigi non vital pada jus buah pir dan dihasilkan perubahan warna gigi dari A3,5 menjadi A3. Jadi dapat ditarik sebuah kesimpulan bahwa Hidrogen Peroksida pada buah pir dapat menjadi alternatif untuk memutihkan gigi.

Faktor yang sangat berpengaruh pada saat pemutihan gigi ialah durasi pemakaian bahan pemutih (waktu kontak). Sehingga, semakin lama dan semakin sering bahan berkontak dengan gigi maka semakin mempercepat perubahan warna gigi. Faktor lain yang mempengaruhi proses pemutihan gigi adalah jenis bahan pemutih, konsentrasi,f aktor cahaya, kenaikan suhu serta tipe diskolorisasi dan warna gigi awal. Plak dan kalkulus juga memiliki potensi mengurangi efektivitas hidrogen peroksida (Adiyanto, 2009)

Menurut penelitian Brennan $\mathrm{T}$, buah pir mengandung hydrogen peroksida yang berfungsi dalam proses oksidasi yang menginisiasi proses pematangan buah. Terjadinya peningkatan hidrogen peroksida dalam jaringan buah, maka dapat mempercepat proses pematangannya. Hydrogen peroksida dalam buah pir dibentuk oleh isolated mitocondria dan chlooroplast. Di dalam $100 \mathrm{mg}$ jaringan buah pir, terdapat sekitar 2 gram hydrogen peroksida saat pematangan dimulai dan akan meningkat seiring dengan pematangan buah tersebut (A-maqassary A, 2013).

Hydrogen peroksida ini diharapkan dapat digunakan sebagai bahan pemutih termasuk gigi melalui radikal bebas reaktif yang dihasilkannya. Radikal bebas tersebut adalah oksigen murni yang 
dapat menghancurkan ikatan-ikatan konjugasi pada molekul zat warna pada noda yang menumpuk baik pada enamel atau dentin. Dengan perusakan ikatan konjugasi, molekul zat warna menjadi molekul yang lebih kecil dan sedikit berpigmen. Inilah yang menyebabkan perubahan warna gigi menjadi lebih putih (A-maqassary $A$, 2013).

\section{SIMPULAN DAN SARAN}

\section{Simpulan}

Berdasarkan hasil penelitian tentang efektifitas buah pir terhadap pemutihan gigi yang dilakukan, dapat disimpulkan bahwa buah pir efektif digunakan sebagai alternatif dalam pemutih gigi. Perbedaan warna gigi sebelum dan sesudah pengaplikasian buah pir dapat dilihat jelas dengan membandingkan hasil penelitian sebelum dan sesudah pengaplikasian dimana warna gigi pada sampel yang diteliti yang tadinya berwarna kekuningan berubah menjadi tampak lebih putih

\section{Saran}

Sesuai dengan hasil kesimpulan, maka peneliti menyarankan penggunaan buah pir sebagai alternatif untuk memutihkan gigi. Penelitian ini memerlukan penelitian lanjutan dan diharapkan agar penelitian berikutnya menggunakan sampel yang lebih banyak

\section{DAFTAR PUSTAKA}

Adiyanto IO. 2009.Pengaruh Lama Perendaman Gigi dengan Jus Buah Pir (Pyrus Communis) Terhadap Perubahan Warna Gigi padaProses Pemutihan Gigi Secara Invitro. Avalaible from URLhttp://eprints.undip.ac.id/14222/1/Intanokt avianaadiyanto.pdf.

Al-Magassary A. 2013. Kandungan Buah Pir. Avalaible from URL : http://www.ejurnal.com/2013/12/Kandungan-BuahPir.html?m=1

Aryulina. (dkk) 2004. Biologi 2. Jakarta : Erlangga. P.169.

Ciptawening AP. 2014. Efektifitas DaunStoberi Terhadap Pemutihan Gigi pada Penghuni Kost Qkan Tirto Agung Barat 4C Semarang[Skripsi]. Universitas Diponegoro Semarang.

Grossman LI. (dkk) 1995. IImu Endodontik Dalam Praktek ed11. Jakarta:EGC. P.295-297.

Hendari R. 2009.Pemutihan Gigi(Tooth-Whitening) pada Gigi yang Mengalami Pewarnaan. Journal; vol XLIV (188): p.66-73.

Meizarini A, Rianti D. 2013. Bahan Pemutihan Gigi dengan Sertifikat ADA/ISO. Dentistry Journal; vol 38 (2): p.74-76..

Pusparatri RA. 2014. Metode Bleaching untuk Pemutihan Gigi. Avalaible from URL: http://www.SeputarGigi.com/site/index.php?o ption=com content\&view=article\&id=98:Meto de-Bleaching

Rahmat M. 2010. Perbedaan Warna Email Gigi Setelah Aplikasi Buah Stroberi dan Karbamid Peroksida. Universitas Hasanuddin Makassar. 